\title{
6. Conversations with Convicted Rapists
}

\author{
Fiona Hukula
}

\section{Abstract}

Does Papua New Guinean culture influence the propensity to rape? Or is it the way in which we are socialised that influences how we treat women? Is rape more common among certain ethnic groups? These are some of the questions that have prompted this research. This chapter is based on interviews conducted with convicted rapists who have been detained at Port Moresby's Bomana Prison. It provides some preliminary insights into the type of men who rape and explores issues such as cultural and peer influence.

\section{Introduction}

When I mention that I'm from Papua New Guinea (PNG), it is not uncommon to hear negative comments regarding the law and order situation and high levels of violence against women. There has been much debate, awareness and lamenting about the situation of women and girls, especially in relation to gender violence and gender equity. A common response to issues of violence against women by Papua New Guineans is that em pasin bilong ol (TP: that's their way) or em nomol ya (TP: that's normal). Such statements insinuate that violence against women is a timeless tradition which is viewed as the norm. Many times we Papua New Guineans categorise issues of gender according to our cultural and ethnic backgrounds. For example, there is a common perception that women who come from matrilineal societies may have more positive experiences of gender equality than those who come from patrilineal societies (Sai 2007). Such stereotypical notions of cultural attitudes and practices are often used to mollify and justify reasons for gender inequality and gender violence.

This chapter attempts to capture the voices and thoughts of Papua New Guinean men who have been incarcerated for rape and sexual offences. Research into the areas of gender relations and gender violence in PNG has long been a topical issue for anthropologists, donor agencies and human rights activists alike. There is an abundance of literature which discusses aspects of violence against women and gender equality from pre-contact times through to the present. Frequently 
referenced are anthropological accounts of gender violence and sexual antagonism in the Highlands of PNG, documented by the likes of Langness (1967), Meggitt (1964) and Read (1981) who interpreted sexual antagonism and male domination over women as solidarity among groups of men. But violence against women is prevalent both in rural and urban Papua New Guinea (Toft 1985; Jenkins and NSRRT 1994; Hammar 1999). Discussions of social change and adaption to urban/modern life also engage with changing gender relations and gender violence, with a particular focus on marital violence (Toft and Bonnell 1985; Brown 1988; Rosi and Zimmer-Tamakoshi 1993; Zimmer-Tamakoshi 1997; Counts 1999; Dinnen and Ley 2000).

These discussions address problems associated with development, such as poverty and lack of educational opportunities. In addition, they connect these problems to the ways in which traditional notions of gender have been translated within the contemporary Papua New Guinean context. Until recently, post independence discourses on gender relations have predominantly focused on how gender inequality affects women, and especially how violence affects women and the causes of gender violence. There has been a gap in such discourses: men's thoughts and experiences of violence and masculinity have not been addressed. This gap has been recognised with ideas of changing masculinities recently discussed by various scholars (Brison 1995; Eves 2006; Sai 2007; Macintyre 2008; Haley 2008; Lepani 2008; and Bainton 2008).

Both Anou Borrey (2000) and Cyndi Banks (1997) suggest that the cultural contexts within which violence against women occur are important in isolating causes and understanding such violence in PNG. Earlier Christine Bradley (1985) argued in a similar way apropos attitudes to and practices of violence in marriage in East New Britain. This chapter follows these authors but focuses on men, through the presentation and discussion of case studies from a small study of men incarcerated as sex offenders at Port Moresby's Bomana Prison. I examine the social context within which the sexual offences were committed.

My initial research interest was centred on the factors influencing how men think and behave in relation to sexual violence. I posed several questions. Are there any differences between men who come from matrilineal societies and men who are from patrilineal societies? Or are there differences between men who were brought up in rural areas as opposed to men who grew up in urban areas? How about those whose parents are not from the same province? These were some of the initial questions which kept circulating in my mind while I tried to grapple with this serious social problem. The conversations with convicted rapists, reported and used below, are the result of my attempts to seek answers to such questions which have preoccupied me over a number of years. My research 
aimed to ascertain information about men who commit rape and other sexual offences, and to elicit information about the upbringing of these offenders and their perceptions about gender.

\section{Methods}

The study was conducted from October to December 2006 at the Bomana Prison, outside Port Moresby. The data was obtained through semi-structured interviews with males who were convicted for sex offences. These crimes included rape, incest and indecent assault. Initially it was envisaged that interviews would be conducted with two offenders from each province, preferably one from a rural area and the other from an urban location. The rationale behind interviewing offenders from the same province who grew up in either a village or a town was to ascertain whether a rural rather than an urban setting made any difference in terms of cultural socialisation. However this comparative approach proved impractical due to the reluctance of some prisoners. The Correctional Service officers assisted me by identifying potential interviewees and they also explained the purpose of the research to the prisoners. Those who agreed to be interviewed were then sent to the interviewer. Interviews were also carried out with Correctional Service officers who work at Bomana Prison. Prison officers have the most contact with prisoners, and through their daily interaction with prisoners they were able to offer insights based on their conversations with the prisoners. A total of fifty prisoners convicted of various sex-related offences were interviewed.

The interviews were conducted by Thomas Semo, who had previous research experience as a research assistant with the Social and Environment and Political and Legal Studies divisions at the National Research Institute. Initially I wanted to carry out the interviews myself. However, on the advice of some of my peers, I was encouraged to recruit a male research assistant. The first day of interviews proved my peers right. I carried out two interviews, one of which went quite well while the second did not. The young man that I interviewed seemed nervous and on edge as the interview was being conducted. He kept looking at his hands and giving short one word answers. I sensed that the prisoners were more comfortable with a male researcher than with me, since throughout most of PNG, men and women do not discuss sexual matters together and most times both parties can be uncomfortable in doing so. Moreover, there was an initial misconception that I was a lawyer who was seeking interviews to build a case to have their (the offenders') sentences lengthened. This, and other misunderstandings about the purpose of the research, was cleared up promptly by Thomas and the Correctional Service officers, who proved very helpful. Thomas asked the inmates a series of semi-structured questions relating to their 
lives and the offences that they had committed. The questions were designed to elicit information about their social and cultural backgrounds and their perceptions and experiences of gender relations.

\section{Age, education, employment, origin and perceptions of gender}

The ages of the men who were interviewed ranged from eighteen to sixty-four with nearly half of the offenders being between eighteen and twenty-five. Twelve of the offenders were over forty years of age. The educational level of the majority of interviewees was between grade six and eight (see Table 3).

Table 3. Highest educational attainment of the sexual offenders interviewed for this study.

\begin{tabular}{|l|l|l|l|l|l|l|l|l|l|l|c|c|}
\hline Grade & 1 & 2 & 4 & 5 & 6 & 7 & 8 & 9 & 10 & Voc/College & University & Never been to school \\
\hline Total & 2 & 4 & 2 & 4 & 18 & 3 & 5 & 1 & 3 & 1 & 1 & 6 \\
\hline
\end{tabular}

Nearly half of the men (22) said that they had had a paid job at one time or another. The types of jobs could be categorised as low-skilled, low-income jobs including a saw mill operator, fuel attendant, baker, carpenter, security guard and green-keeper. One person identified himself as a subsistence farmer and another as a fisherman while two said they were part of the informal sector; one specifically was in the business of money lending.

Twenty-eight of the fifty offenders spent most of their childhood in their place of ethnic origin while twenty-two men spent their childhood elsewhere (see Table 4). Of those twenty-two men, six stated that their parents taught them about their customs and seven said that they went to their village often. Those who were brought up in their villages said that they knew about customs relating to women. The level of knowledge of custom claimed was the same for those who grew up in their place of ethnic origin and those who grew up elsewhere. The three common responses apropos customs relating to men and women were that (1) the man owns the land; (2) the man is the head of the family; and (3) the man inherits land (except for matrilineal societies). In reality land is usually owned by groups, such as clans or lineages, and divided among members. The general consensus among those interviewed was that women are generally valued for what they bring to a man's family or clan: for her ability to bear children and for her contribution to activities such as gardening. From the perspective of her own family and clan a woman is valued because she is a potential source of bride price. 
Table 4. Place of origin and where the interviewed offenders grew up.

\begin{tabular}{|l|l|l|}
\hline Place of Birth & $\begin{array}{l}\text { Number of } \\
\text { interviewees }\end{array}$ & $\begin{array}{l}\text { Spent most of childhood } \\
\text { in Home Province }\end{array}$ \\
\hline Eastern Highlands & 6 & 2 \\
\hline Central & 10 & 9 \\
\hline Gulf & 1 & 1 \\
\hline Madang & 1 & 1 \\
\hline Southern Highlands & 2 & 2 \\
\hline East Sepik & 1 & 1 \\
\hline NCD & 12 & \\
\hline Simbu & 3 & 3 \\
\hline Sandaun & 2 & 1 \\
\hline Enga & 1 & \\
\hline Milne Bay & 3 & 3 \\
\hline Western & 5 & 4 \\
\hline Morobe & 2 & 1 \\
\hline New Ireland & 1 & \\
\hline Totals & 50 & 28 \\
\hline
\end{tabular}

Over half the offenders (31) knew their victims. Eight of the victims were family members, including step daughters and adopted daughters, nieces, a sister and other distant relatives. Four offenders claimed that the victim was in a relationship with them or had consented to sex. Seventeen of the offenders stated that the victims were either girls from the communities in which they lived or were acquaintances known through friends and relatives. Previous research by the Papua New Guinea Institute of Medical Research (1994), Banks (1997) and Borrey (2000) has also indicated that most of the violence against women is carried out by men who are known to the victims.

Nine of the men who were interviewed had been in prison before; two for rape and seven for various other crimes ranging from robbery, stealing and motor vehicle-related incidents.

\section{Retrospective rationalisations on rape}

The offenders discussed their actions retrospectively and offered some insights into why they had committed the crimes. In an effort to reflect some of these insights I have included several anecdotes based on conversations with the offenders, followed by four more extended studies. The following discussion on some of the conversations gives a sense of the range of retrospective explanations for their behaviour. 
Sibling or family pressure featured in the responses of several of the convicted offenders. An eighteen-year-old single man explained that, 'he was with his elder brothers and they forced him to rape the girl. He didn't want to do it but his brothers forced him and because he respected them, he did it.' In another case, a twenty-eight-year old unmarried man associated his crime with his parents who 'stopped him from getting married and he got angry and committed this crime to frustrate his parents.'

Alcohol was a contributing factor in several rape cases. A twenty-four-yearold unmarried man said, 'he was under the influence of alcohol and he took his girlfriend to his auntie's house and slept with her with her consent. The next morning the girl's relatives found out and demanded compensation from him. He refused to pay compensation so the girl's family took the matter to the police. The girl was also engaged to another man when the incident happened.' Another man who was twenty-five years old and single reported that both he and the victim were 'drunk and he raped the girl. He later realised what he had done and surrendered himself to the police.' Yet another, a thirty-seven-year-old man with two children, said that he was drinking with his friends along the street and it was late in the night ... a woman and her husband walked past. He chased the man away and abducted his wife into the nearby block and raped her.'

Other convicted rapists blamed their actions on their wives for withholding conjugal rights. As one thirty-year-old married man with one child explained, 'his wife didn't spend enough time with him to make love.' A second man with seven children said that 'his wife often accused him of having affairs with village ladies. The incident happened when they were under the influence of alcohol, the victim gave her consent. His wife didn't allow him to have sexual relations with her.'

Some of the men blamed peer pressure and pornography for their crimes. One single twenty-four-year-old rapist explained 'he did it because his friends were doing it. He was also influenced by porn. He'd been viewing Playboy magazines since he was twelve.' Another single nineteen-year-old watched two pornographic CDs with his friends. 'When they finished they walked across the block where they saw the girl sleeping by herself on the verandah of her house. They dragged her down to the drain and raped her.'

For others revenge was what impelled them to rape. 'The victim accused [a 22-year-old single man] ... of stealing her small brother's bicycle and selling it to one of their relatives' and so he raped her.

Some other men said that they had been set up or tricked into having what they thought was consensual intercourse with the victims. As a thirty-year-old man 
with two wives and three children explained, 'the girl was from an enemy tribe, her brother set him up. They got the girl to sleep with him then accused him of rape. He slept with the girl with her consent.' In another case, the fifty-sevenyear-old rapist with three children 'was set up by his wife's first husband,' and a thirty-four-year-old widower with two children claimed that the family of the victim set him up because he had not given them any money since he began working.'

In other instances unrequited desire was a contributing factor. A twenty-twoyear-old single prisoner said that 'he was attracted to the girl but didn't know how to approach her.' A twenty-four-year-old bachelor said that he had fallen 'in love with the victim a long time ago and couldn't control his desires.' In yet another case, a widower with seven children 'wanted to remarry but his late wife's relatives stopped him from getting married to another woman. He got frustrated and committed incest with his fifteen-year-old niece who was related to him through his wife.'

Finally, witchcraft is blamed for one man's actions. A forty-three-year-old man with three children raped a woman because 'it was believed that the victim's bubu [grandparent] killed his cousin's brother through witchcraft.'

With the exception of pornography, which presents an interesting theme for future analysis, I would now like to explore the other recurrent themes in more detail by examining five individual cases.

\section{Taking responsibility?}

\section{Case One: She owed us!}

PK is twenty-five years old, the fourth child in his family and the father of one child. He was born in Henganofi, Eastern Highlands and spent most of his childhood in Port Moresby. PK never went to school because he ran away from school when his parents tried to enrol him at the local Catholic school. His mother did not attend school while his father went up to Grade 2. In Port Moresby his mother did not work in the paid workforce and his father, who is now retrenched, was employed by a government department. PK had worked as a security guard for a local security firm in Port Moresby. He stated that according to his knowledge of his custom, men own land and women are important because their family will receive bride price for them. At the time of the interview he had served five years of his twelve-year sentence for abduction and rape. He said that his victim, a nineteen-year-old girl from another Highlands province, borrowed 100 kina each from him and his friend 
and didn't repay them. He and his friend approached her one evening at her house when her parents were away. She told them that she had no money to repay her debts. They then demanded that she find money somewhere to repay debts but she refused and they got mad and raped her.

\section{Case Two: Revenging girls who slept with men from another village}

UM is twenty-two years old, single and comes from the Trobriand area of Milne Bay Province. He was born and brought up in the village and completed his primary education at the local primary school. According to UM, men in his area possess yam-planting powers. He said that as he was growing up boys and girls mixed around freely and boys mixed with girls who had their breasts uncovered as this was normal and part of their matrilineal custom. He was told by his parents that this was how things had been for a long time. At the time of the interview, UM was serving a nineteen-year eight-month sentence for raping two nineteen-year-old girls. He committed the offence with three others. According to UM he and his friends committed the offence because the girls were from their village, but they had slept with men from another village. UM and his friends went to fight the men but they ran away so they belted the girls up badly. According to UM the girls then enticed them to have sex with them, so they did. Later two of the girls reported the matter to their parents and their parents reported the matter to the police and they were arrested.

\section{Case Three: Drunken rape of a niece since wife avoiding pregnancy}

ML is thirty-eight years old, married with four children. He was born and brought up in his village in Madang Province. He completed year ten at Brahman High School before moving to Port Moresby. Both his parents were subsistence farmers. He said that in his place men are told about important resources of the clan and they are also told stories from the grandparents and fathers about clan land boundaries and stories about their origin. He also said that when a woman gives birth she abstains from gardening and other household tasks for a period of time until a feast is celebrated to release her from confinement. At the time of the interview ML was serving a seven-year and one-month sentence for carnal knowledge of his twelve-year-old niece. He said he was very drunk when he committed the offence. His wife had stopped him from sleeping with her because they already had four children and she didn't want to look after any more children. He then had affairs with other women which frustrated his wife. 
He said his wife always got angry at him when he returned home from work and his wife's elder sister usually supported her. These factors caused him to get drunk and do what he did.

\section{Case Four: Unrequited love - and power!}

LM is thirty years old, single and from Ihu in the Gulf Province. He was born in Ihu and spent his childhood in his village, where he completed primary education. His mother is a subsistence farmer and his father worked as a handyman in Kerema town. LM was brought up to respect girls and said that he did not take part in custom-related activities. At the time of the interview, LM had been sentenced to six years, five months and three weeks for unlawful carnal knowledge. LM said the girl was the most beautiful girl in the village and he sent word for her several times but she rejected his request. He got angry and one time when she was by herself he went and approached her to be his girlfriend but she swore at him. He tried to calm her down but he couldn't. He then stripped her and raped her.

\section{Case Five: Overcrowding, incest and anger}

HTS is forty-seven years old, and was born and raised in Port Moresby. He was educated to Grade 8. He's the second child in a family of nine. He is separated and is the father of two children. His mother is a housewife and his father worked in Port Moresby. He was raised in the Jehovah Witness religion. HTS was brought up in Port Moresby and rarely went to his village in the Gulf Province, therefore, he says, he didn't know much about custom and hadn't been through any initiation ceremonies. The first time he went to his village was when he was twenty years old and he found it difficult to stay there. He considers village life to be boring. At the time of the interview, HTS was serving a four-year twomonth sentence for sexual penetration of his nine-year-old sister. HTS says he got frustrated because the house he was living in was overcrowded and he did what he did in order to scare his other family members so they would leave the house. Also his wife had left him fourteen years earlier and when he wanted to get married to other women his children and family discouraged him. This he says also made him angry.

\section{The offender as victim}

The preceding anecdotes are based on stories told by the prisoners themselves. Their stories suggest their reasons for their actions, from various points of 
view. Their retrospective discussion suggests that their ideas of gender are not confined merely to the description of male/female relations, but reflects a wider sociality. This insight will be used in analysis, to highlight several themes.

\section{Avoiding pregnancy}

In several interviews and especially outlined in Case Three some of the prisoners justified their actions by stating that their wives did not want to have sex with them for various reasons including not wanting to get pregnant. In this scenario the withholding of sex by the offenders' partners is perceived as a contributing factor in the committing of the offence.

\section{Retribution}

A second theme that runs through the interviews is the issue of retribution, which exemplifies, from the view of the offender, how rape is a means of eliciting a response for a prior social misdemeanour. It is therefore plausible to assume here, again from the offenders' points of view, that the action and meaning of the rapes took the form of 'restitutive actions' rather than unprovoked serious offences or crimes. The elucidation of a prior transaction or event, such as that of money being borrowed, or the death of a relative, was seen as a justification for such actions. Such findings are similar to those of Banks (1997). She offers an example of a man who was sentenced to prison for raping a thirteen-year-old girl as 'payback' because she accused him of stealing from her and she insulted him by swearing at him. Furthermore her father accused him of stealing his chickens and insulted and swore at him. These insults were further fuelled by his reasoning that the victim's brother raped his sister and, although the matter was reported to the police, no action was taken.

\section{Frustration}

Frustration is an emotion which is mentioned frequently in the conversations. Men were frustrated by their wives, by their families and by their circumstances. More specifically their frustration stemmed from issues related to sex. A husband was frustrated by his wife's refusal to have sex. A widower was frustrated by his late wife's family's refusal to allow him to remarry. A young man was angry because his parents stopped him from getting married. These prisoners constructed these prior conditions as the primary causes of their actions.

For example, in Case Three, ML's wife had stopped sleeping with him and he thus had affairs with other women to mitigate his sexual frustrations and also to frustrate his wife. As reflected in Case Five, HTS was frustrated that his house 
was overcrowded and he felt an additional source of anger because his wife had left him fourteen years earlier and when he wanted to remarry his children and relatives had discouraged him. Not being able to assert their masculinity by being in sexual relationships may be viewed by some men as a form of frustration which leads to sexual offences being committed. They perceive a lack of control of their emotions, such as the expression of frustration due to rejection from wives or from girls they admire. This suggests a fragile, resentful predisposition in male sexuality in contemporary PNG, similar to Wardlow's (2007) portrait of Huli men.

\section{Set up}

Three of the offenders stated that they were 'set up'. The offenders claimed that various people related to the victim arranged for the incidents to happen. The 'set ups' occurred for various reasons: the offender did not give money to the family or the offender was from an enemy tribe. Here we see the offenders deflecting attention away from their rapes through the projection of responsibility onto distant causes. A perceived pre-existing tension was being used as a social cause of their actions, such that the offenders viewed themselves as the victims of predetermined actions. In general offenders constructed prior conditions in which their actions were more about eliciting some form of action from others. Indeed, many offenders did not consider rape to be a deviant act but rather the result of others' actions.

\section{Consensual sex}

Consensual sex is mentioned in two of the anecdotes, although, as noted by Stewart (2005: 6) the issue of consent in rape, so crucial to the introduced law's definition of the offence, is not necessarily central in customary ways of thinking (see also Borrey 2000). The Correctional Service Officers who were interviewed stated that possibly some cases involving young men could have been consensual sex, but the girls' parents did not agree with the relationship and they were then charged with rape.

\section{Matriliny}

There is not sufficient data to verify if there are any major differences between matrilineal and patrilineal societies. Case Two illustrates an example where the offender states 'as he was growing up boys and girls mixed around freely and boys mixed with girls who had their breasts uncovered as this was normal 
and part of their custom and they have lived and grown up with this.' In this particular case the offender is from a matrilineal society and the victims were from his own village in Milne Bay Province.

\section{Alcohol}

This research has demonstrated that alcohol is an enabling factor rather than a cause in the majority of cases. Men use their state of inebriation as a means not only to give them the confidence to act out such behaviour but also to justify their actions. According to Macintyre 'beer drinking is a form of conspicuous consumption that in PNG denotes modern masculinity. It is the way that many men display their economic achievement' (2008: 188). But the consumption of alcohol is both a trigger and a facilitating factor in many of the cases. In my research the men may not necessarily be displaying their economic achievements since, as low-skilled, low-income workers, their income-generating opportunities are limited.

\section{Concluding thoughts on rape and power}

In the past young men were guided through the transition from boyhood to manhood. Initiation ceremonies entailed young men gaining knowledge from their elders on subjects including women and courting and prepared them for adulthood and marriage. In many parts of PNG, both rural and urban, these rites of passage have been eroded due to Christian missionary influences and changing lifestyles. This rupture has lead to more violent contemporary forms of masculinity among groups such as the Duna of Lake Kopiago District, in Southern Highlands (Haley, 2008). Nicole Haley succinctly presents a narrative of masculine embodiment through her juxtaposition of 'traditional' and contemporary growth-enhancing spells and songs. Through the retelling of songs she shows how the ideals of masculinity have been transformed from being growth-enhancing proud songs to songs of insecurity and woe. The Palena bachelor cult which once dominated the lives of young Duna men has now been eroded with the arrival of Christianity and colonialism. Local masculinities have now emerged with young men's behaviour being moulded by guns and marijuana. Martha Macintyre (2008: 181) in her portrayal of gutpla stail (TP: male presentation in the forms of dress and behaviour) also addresses violence in styles of modern masculinity. She posits that contemporary styles of comportment portray a look that expresses a capacity for violence (2008: 185). The cut off jeans and the cargo pants worn by young men, and the 
combat trousers, bandanas and dark glasses worn by police riot squads and defence personnel embody the ideal of a modern masculinity which draws upon traditional ideas of the male body as strong and capable of violence.

One of the reasons for initiating this research was to find out more about the social background of the men who have been incarcerated for sexual offences. Various social factors have been viewed as contributing to the propensity to rape and commit such as lack of education, family breakdown, peer influence and drug and alcohol abuse (Harris 1988; Goddard 1995; Sikani 1997; Po'o 1975).

Many researchers, academics and political commentators in PNG, as in the West, have argued that rape is an act of exerting male power over women. Laura Zimmer-Tamakoshi (1990) posits that most popular explanations of contemporary sexual violence ignore sexual exploitation in traditional Papua New Guinean societies. She suggests that sexual aggression in traditional Papua New Guinean societies has been transformed into contemporary gender violence in PNG. 'New ideas about women's inferiority and men's right to dominate them have, in many instances, been grafted onto older sets of beliefs, thereby contributing to women's alienation and an increase in violence against women' (1990: 259). Similarly, Banks (1997) concurs that violence by men against women appears to arise most often when men perceive they have lost control over women; when women are perceived by men to have breached certain expectations of conduct; and when there are underlying prior injuries within the family.

I suggest that the idea of 'power' which is often used to explain such gender violence has western connotations. In saying this I am not denying that gender relations in Melanesia are grounded in relations of power. The idea of 'power' which I evince is one which is internalised as sexual violence and acted out through engagement with a wider field of social relations and not that of an isolated individual. The acting out of social relations which is at the core of Melanesian sociality provides the environment for which these explanations of sexual violence are eminent. Perceiving male power and domination over women as the sole cause does not adequately take into account the social contexts within which these acts take place - the broader realm of Melanesian sociality. Actions and consequences involve more than a man and a woman. The rhetoric of power and domination is prevalent in the explanation of rape and other offences against women in PNG. Instead of viewing the reasons offered by rapists simply as 'excuses', I seriously consider the broader context within which the offender situated the events. The power and domination of a man over a woman may not be the only or the foremost reason why these acts were carried out. However, there is still the problem of why more generalised anger and aggression is directed towards women. 
In conclusion, I would advocate attempting to hear the voices of those who commit such crimes so that we are able to get a glimpse of how they are thinking. By listening to their voices we may be able to ascertain the reasons for such actions. As I have argued, the material presented reveals the pervasive themes of frustration and retribution and the need to express masculinity through sex as a justification for rape. It shows that in contemporary PNG men are negotiating their way through relationships with women in a way which is far removed from 'traditional' societies. It is important to understand the ways in which the broader relations of modernity are being transformed as it may lead us to rethink how we choose to deal with the issue of rape and sexual violence in Papua New Guinea.

\section{References}

Bainton, Nicholas A., 2008. Men of kastom and the customs of men: status, legitimacy and persistent values in Lihir Papua New Guinea. In Changing Pacific Masculinities, ed. John P. Taylor. Special issue of The Australian Journal of Anthropology 19(2): 194-212.

Banks, Cyndi, 1997. Contextualising sexual violence: rape and carnal knowledge in Papua New Guinea. In Reflections on Violence in Melanesia, ed. Sinclair Dinnen and Allison Ley, 83-100. Sydney: Hawkins Press and Asia Pacific Press.

Borrey, Anou, 2000. Sexual violence in perspective: the case of Papua New Guinea. In Reflections on Violence in Melanesia, ed. Sinclair Dinnen and Allison Ley, 115-18. Sydney: Hawkins Press and Asia Pacific Press.

Bradley, Christine, 1985. Attitudes and practices relating to marital violence among the Tolai of East New Britain. In Domestic Violence in Papua New Guinea, ed. Susan Toft, 33-71. Law Reform Commission of Papua New Guinea Monograph, 3. Port Moresby: Law Reform Commission of Papua New Guinea.

Brison, Karen, 1995. Changing constructions of masculinity in a Sepik society. Ethnology 34: 155-75.

Brown, Paula, 1988. Gender and social change: new forms of independence for Simbu women. Oceania 59(2): 123-42.

Counts, Dorothy, 1999. 'All men do it': wife beating in Kaliai, Papua New Guinea. In To Have and To Hit: Cultural Perspectives on Wife Beating, ed. Dorothy A. Counts, Judith K. Brown and Jacquelyn C. Campbell, 73-86. Urbana: University of Illinois Press. 
Dinnen, Sinclair and Allison Ley, eds, 2000. Reflections on Violence in Melanesia. Sydney: Hawkins Press and Asia Pacific Press.

Eves, Richard, 2006. Exploring the Role of Men and Masculinities in Papua New Guinea in the 21st Century: How to address violence in ways that generate empowerment for both men and women. Report for Caritas Australia. Online: http://www.baha.com.pg/downloads/Masculinity\%20and\%20 Violence\%20in\%20PNG.pdf. Accessed 28 November 2010.

Goddard, Michael, 1995. The rascal road: crime, prestige, and development in Papua New Guinea. The Contemporary Pacific, 7(1): 55-80.

Haley, Nicole, 2008. Sung adornment: changing masculinities at Lake Kopiago Papua New Guinea. In Changing Pacific Masculinities, ed. John P. Taylor. Special issue of The Australian Journal of Anthropology 19(2): 213-29.

Hammar, Lawrence, 1999. Caught between structure and agency: the gender of violence and prostitution in Papua New Guinea. Transforming Anthropology 8(1/2): 77-96.

Harris, Bruce, 1988. The rise of rascalism: action and reaction in the evolution of rascal gangs. Discussion Paper 24. Port Moresby: Institute of Applied, Social and Economic Research.

Jenkins, Carol and the National Reproduction Research Team (NSRRT), 1994. National Study of Sexual and Reproductive Knowledge and Behaviour in Papua New Guinea. Monograph 14. Goroka: Papua New Guinea Institute of Medical Research.

Langness, L.L., 1967. Sexual antagonism in the New Guinea Highlands. Oceania 37(3) (March): 161-77.

Lepani, Katherine, 2008. Mobility, violence, and the gendering of HIV in Papua New Guinea. In Changing Pacific Masculinities, ed. John P. Taylor. Special issue of The Australian Journal of Anthropology 19(2): 150-64.

Macintyre, Martha, 2008. Police and thieves, gunmen and drunks: problems with society in Papua New Guinea. In Changing Pacific Masculinities, ed. John P. Taylor, Special issue of The Australian Journal of Anthropology 19(2): 179-93.

Meggitt, Mervyn J., 1964. Male-female relationships in the Highlands of Australian New Guinea. American Anthropologist 66: 257-72.

Po'o, Tau, 1975. Gangs in Port Moresby. Waigani: Administration for Development 2: 30-37. 
Read, Kenneth E., 1981. Male-female relationships among the Gahuku-Gama: 1950 and 1981. Social Analysis 12: 66-78.

Rosi, Pamela and Laura Zimmer-Tamakoshi, 1993. Love and marriage among the educated elite in Port Moresby. In The Business of Marriage: Transformations in Oceanic Matrimony, ed. R. Marksbury, 175-204. Pittsburgh: University of Pittsburgh Press.

Sai, Anastasia, 2007. Tamot: Masculinities in transition in Papua New Guinea. PhD thesis, Melbourne: Victoria University.

Sikani, Richard, 1997. Live to steal and steal to live: juveniles and economic crime. Preliminary paper National Research Institute, Papua New Guinea. Political \& Legal Studies Division, no. 3.

Stewart, Christine, 2005. Sex, gender and the law in Papua New Guinea. Discussion Paper No 12. Gender Relations Centre, Research School of Pacific and Asian Studies. Canberra: The Australian National University.

2008. Men behaving badly: sodomy cases in the colonial courts of Papua New Guinea. Journal of Pacific History 43(1) (June): 77-93.

Taylor, John P. ed., 2008. Changing Pacific Masculinities. Special issue of The Australian Journal of Anthropology 19(2).

Toft, Susan, 1985. Domestic Violence in Papua New Guinea. Monograph No. 3. Law Reform Commission, Port Moresby: Papua New Guinea.

Toft, Susan and Suzanne Bonnell, 1985. Marriage and Domestic Violence in Rural Papua New Guinea. Occasional paper 18. Law Reform Commission Papua New Guinea. Port Moresby: Papua New Guinea Law Reform Commission.

Wardlow, Holly, 2007. Men's extramarital sexuality in rural Papua New Guinea. American Journal of Public Health 97(6): 1006-14.

Zimmer-Tamakoshi, Laura, 1990. Sexual exploitation and male dominance in PNG. In Human Sexuality in Melanesian Cultures, ed. Joel Ingebrittson, 25067. Point 14. Goroka: Melanesian Institute.

1997. 'Wild pigs and dog men': rape and domestic violence as 'women's issues' in Papua New Guinea. In Gender in Cross-Cultural Perspective, ed. Caroline Brettell and Carolyn Sargent, 2nd edition, 538-53. Upper River: Prentice Hall. 